\title{
Angiosperm-like pollen and Afropollis from the Middle Triassic (Anisian) of the Germanic Basin (Northern Switzerland)
}

\author{
Peter A. Hochuli ${ }^{1 *}$ and Susanne Feist-Burkhardt ${ }^{2}$ \\ 1 Palaeontological Institute and Museum, University of Zürich, Zürich, Switzerland \\ ${ }^{2}$ Dr. Susanne Feist-Burkhardt Geological Consulting \& Services, Ober-Ramstadt, Germany
}

Edited by:

Xin Wang, Chinese Academy of

Sciences, China

Reviewed by:

Michael S. Zavada, Seton Hall

University, USA

James A. Doyle, University of

California, Davis, USA

Evelyn Kustatscher, Naturmuseum

Südtirol, Italy

Limi Mao, Nanjing Institute of

Geology and Palaeontology, China

*Correspondence:

Peter A. Hochuli, Palaeontological Institute and Museum, University of Zürich, Karl-Schmid-Strasse 4,

Zürich, CH-8006, Switzerland

e-mail: peter.hochuli@erdw.ethz.ch

Here we report on angiosperm-like pollen and Afropollis from the Anisian (Middle Triassic, 247.2-242.0 Ma) of a mid-latitudinal site in Northern Switzerland. Small monosulcate pollen grains with typical reticulate (semitectate) sculpture, columellate structure of the sexine and thin nexine show close similarities to early angiosperm pollen known from the Early Cretaceous. However, they differ in their extremely thin inner layer (nexine). Six different pollen types $(I-V I)$ are differentiated based on size, reticulation pattern, and exine structure. The described pollen grains show all the essential features of angiosperm pollen. However, considering the lack of a continuous record throughout the lower part of the Mesozoic and the comparison with the oldest Cretaceous finds we suggest an affinity to an angiosperm stem group. Together with the previously published records from the Middle Triassic of the Barents Sea area the angiosperm-like pollen grains reflect a considerable diversity of the parent plants during the Middle Triassic. Sedimentological evidence and associated palynofloras also suggest a remarkable ecological range for these plants. Associated with these grains we found pollen comparable to the genus Afropollis. Representatives of this genus are commonly recorded in Lower Cretaceous sediments of low latitudes, but until now had no record from the lower part of the Mesozoic.

Keywords: Middle Triassic, angiosperm-like pollen, angiosperm stem group, Afropollis, confocal laser scanning microscopy

\section{INTRODUCTION}

In spite of extensive research the origin and temporal and spatial distribution of early flowering plants are still a matter of debate. Current research on the origin of angiosperms follows two lines of evidence-the fossil record and molecular data. Molecular data provide a framework for the origin of the crown group of flowering plants as well as for the successive appearance and relationships of the various clades. A wealth of molecular data has been published over the last two decades (for references see Frohlich and Chase, 2007; Soltis et al., 2010, 2011; Doyle, 2012). However, so far no consensus about the first appearance of the angiosperms has been reached. Different data as well as methods have resulted in significantly different ages ranging from the Palaeozoic to the Cretaceous (e.g., Bell et al., 2010; Magallón, 2010; Smith et al., 2010; for a recent overview see Doyle, 2012 and Magallón et al., 2013).

In this paper we focus on fossil evidence, presenting the so far oldest angiosperm-like pollen from the Middle Triassic (ca. $243 \mathrm{Ma}$ ), a record that predates the generally accepted first occurrence of angiosperm pollen by more than $100 \mathrm{Ma}$. The first known fossil angiosperm pollen grains as well as those of the most basal living species are described as columellate and monosulcate. That means they have one distal slit-like aperture (sulcus) and a wall structure including column like elements (columellae). The multilayer wall (exine), which is commonly preserved in the fossil record, consists of the thin innermost endexine followed by an adjacent thin layer, termed footlayer. The following columellate layer, consisting of rod like elements, roots in the footlayer and connects it to the outermost layer called tectum. Since endexine and footlayer are commonly indistinguishable-especially in light microscope studies - the term nexine has been introduced. The term sexine is used to designate the outer layer consisting of the columellate layer and the tectum. In the present study the term nexine is consistently applied for the inner layer, since with the presently used optical means endexine and footlayer cannot be differentiated. The tectum of the above mentioned pollen grains is commonly discontinuous or perforated, which is described with the term semitectate. Thus, the complex morphology of the exine of angiosperm pollen permits to distinguish them from superficially similar palynomorphs, like gymnosperm pollen, some spores, dinoflagellate cysts or other algal and fungal remains.

In the present study we discuss finds of angiosperm-like, monosulcate and columellate pollen grains in the context of the earliest Cretaceous and other pre-Cretaceous records. Early Cretaceous diversification and evolutionary success of flowering plants is well documented by numerous finds of pollen and megafossils - such as flowers, wood, seeds, and leaves. The earliest accepted records are essentially based on dispersed pollen grains, which due to their high numbers and their high preservation potential represent the most appropriate tool to trace the timing of early angiosperm evolution. The presence of 
angiosperm pollen in biostratigraphically dated marine sediments provides the possibility to precisely calibrate the essential steps in angiosperm evolution (Muller, 1981; Hughes, 1994; Heimhofer et al., 2005; Doyle, 2012).

The first broadly accepted records of angiospermous pollen grains are known from the earlier part of the Early Cretaceous (Valanginian-early Hauterivian) (Gübeli et al., 1984; Trevisan, 1988; Brenner, 1996). However, within this interval they are extremely rare; continuous records exist only from the Barremian onwards, and this only for low and mid-latitudes (Hickey and Doyle, 1977; Crane and Lidgard, 1989; Hughes, 1994; Schrank and Mahmoud, 2002). Based on their subsequent increase in abundance and diversity it has been assumed that angiosperms originated in the Early Cretaceous (e.g., Hughes, 1994; Brenner, 1996; Friis et al., 2011). However, some authors suggest that the "sudden appearance" on most continents as well as the rapid radiation of numerous clades during the latter part of the Early Cretaceous point to an earlier origin of the group, probably going back to the Jurassic (e.g., Stuessy, 2004; Doyle, 2012), to the Triassic or even to the Palaeozoic (Zavada, 2007; Clarke et al., 2011). Cornet $(1977,1989 b)$ was the first who reported on occurrences of pollen grains with angiospermous features from Triassic sediments. However, these records are commonly regarded as inadequate evidence for an earlier origin of the group (e.g., Friis et al., 2011). But so far the search for unequivocal evidence (fossil flowers and carpels) from pre-Cretaceous sediments was unsuccessful. Either the age of the sediment containing larger plant remains was erroneous (Sun et al., 1998; He et al., 2004, 2006) or the plant fossils were not sufficiently well preserved to allow for unambiguous interpretation (Wang et al., 2007; Wang, 2009, 2010; Zheng and Wang, 2010; Friis et al., 2011; Doyle, 2012). From the same area as the angiospermlike pollen grains we report on the oldest occurrence of the genus Afropollis. This group, considered by some authors as of angiospermous affinity, is so far known to be restricted to the Cretaceous (Barremian-Cenomanian). Its presence in Middle Triassic sediments opens another observation gap of over $100 \mathrm{Ma}$.

\section{LOCATION AND STRATIGRAPHIC CONTEXT}

The illustrated pollen grains have been observed in samples from two core holes in Northern Switzerland (Weiach and Leuggern, Figure 1). During the Middle Triassic the site in Northern Switzerland was located at a palaeolatitude of about $20^{\circ} \mathrm{N}$. A continuous Middle Triassic section was recovered from the Weiach core hole (Matter et al., 1988, and Figure 2). The studied interval includes the uppermost part of the Buntsandstein (Plattensandstein), the lower part of the Muschelkalk (Wellenkalk/Wellenmergel) and the middle part of the Muschelkalk (Sulfatschichten) representing a typical succession for the southern part of the Germanic Basin (for geological details see Figure 2 as well as Matter et al., 1988; Peters et al., 1989).

The described pollen grains have been observed at two distinct levels of the Weiach core hole (Figure 2). The sample containing Afropollis comes from the Wellenkalk unit (Lower Muschelkalk), which consists essentially of gray siltstones. The associated palynological assemblage consists of typical elements

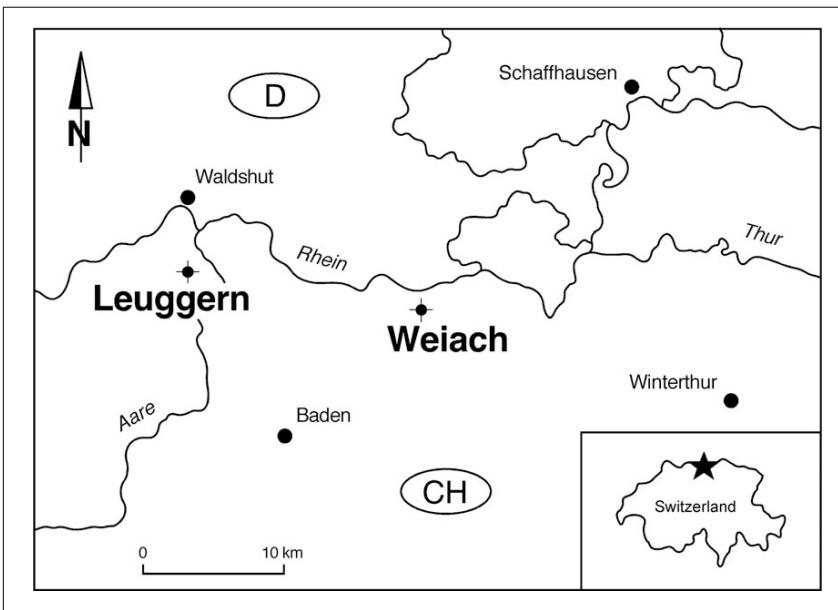

FIGURE 1 | Location of the Weiach and Leuggern core holes.

of the early Anisian (Aegean) including Stellapollenites thiergartii, Tsugaepollenites oriens, Densoisporites nejburgii, and Platysaccus leschikii (see Kürschner and Herngreen, 2010; Hochuli et al., 2012). Another record of Afropollis (Afropollis sp. II) has been found in the same unit of the neighboring Leuggern core hole.

The occurrence of the angiosperm-like pollen is restricted to the upper part of the Sulfatschichten (Middle Muschelkalk), which is dominated by evaporites. The associated palynoflora consists also of typical Anisian taxa including Stellapollenites thiergartii, Tsugaepollenites oriens, Podosporites amicus, Institisporites spp., as well as frequent occurrence of Protodiploxypinus and a few representatives of the Circumpolles group (e.g., Duplicisporites tenebrosus and Paracirculina spp.) (Hochuli et al., 2012). Dominating elements are conifer pollen of the Triadispora group whereas spores are rare. This assemblage is interpreted to be of middle to late Anisian (Pelsonian/Illyrian) age (see Kürschner and Herngreen, 2010; Hochuli et al., 2012).

\section{MATERIALS AND METHODS}

Afropollis has been found in the fine-grained dominantly siliciclastic Wellenkalk unit (Lower Muschelkalk) of the Weiach core hole $(950.82 \mathrm{~m})$ and in the same unit of the nearby Leuggern core hole $(171.63 \mathrm{~m})$. The angiosperm-like pollen grains have been found in a short interval (901.91-905.99 m) of the Sulfatschichten of the Weiach core hole. The samples originate from interbedded gray silty layers in this evaporite dominated interval. The described angiosperm-like pollen grains are very rare, representing $<1 \%$ of the pollen counts. In the studied sections palynomorphs are well preserved and show no sign of thermal alteration (Thermal Alteration Index <2; Staplin, 1982); however, they are strongly compressed. Contamination of the samples can be excluded since recent pollen grains would be three-dimensionally preserved and the described pollen types differ from superficially similar grains from Cretaceous and younger sediments.

The samples were processed according to standard palynological procedures (Traverse, 2007). The slides were produced by embedding the organic residues in epoxy resin. They were 


\section{Depth Lithostratigraphy}

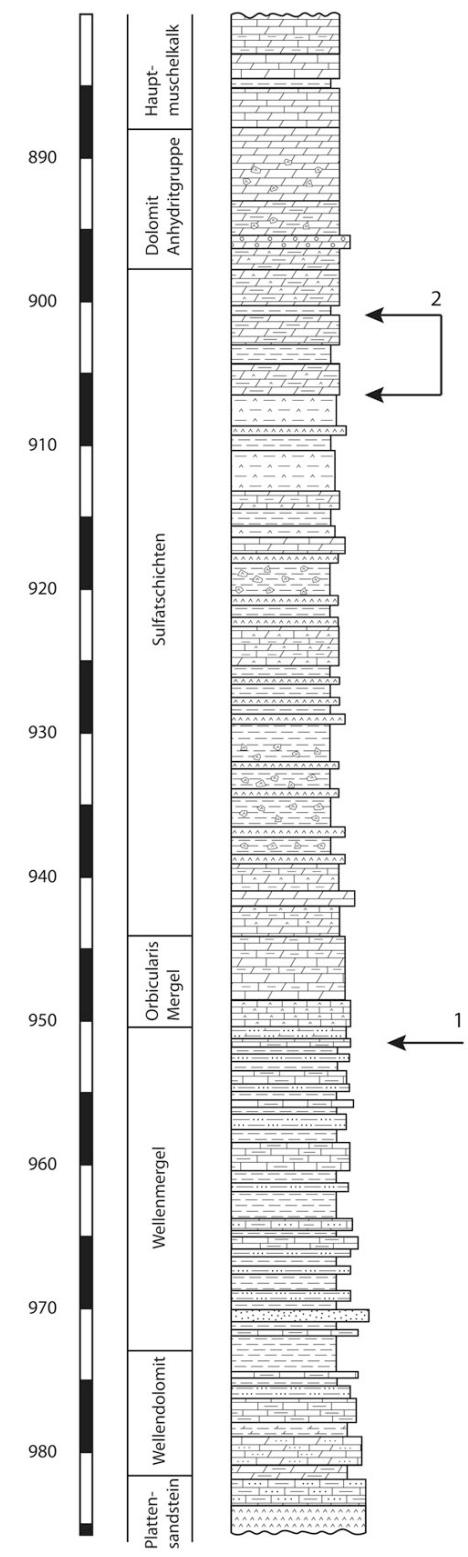

FIGURE 2 | Lithostratigraphic column of the Middle Triassic section of the Weiach core hole. 1, position of Afropollis; 2, range of angiosperm-like pollen grains.

studied first using a standard microscope with transmitted light (Olympus BX51). Light microscope images were taken with an Olympus digital camera (Olympus DP12). Subsequently the described pollen grains were analyzed using confocal laser scanning microscopy (CLSM). CLSM is an optical imaging technique allowing for the capture of high resolution, blurfree fluorescence images and image stacks of optical sections through an embedded specimen. It enables the reconstruction of three-dimensional structures from the obtained image stacks.
The technique is non-destructive and particularly suited to the analysis of palynomorphs. Because of the autofluorescence of most organic-walled microfossils standard palynological slides can be analyzed without any further preparation. Its application to fossil organic-walled dinoflagellate cysts was first described in detail by Feist-Burkhardt and Pross (1999). Hochuli and FeistBurkhardt (2004) used CLSM in the morphological analysis of Triassic angiosperm-like pollen grains. In this paper we show some associated gymnospermous pollen grains for comparison. The confocal laser scanning images show the distinct differences in the structure of the pollen grains. Confocal images were taken on a Leica TCS SP confocal microscope using 40x or 100x objectives under oil immersion at an excitation wavelength of $488 \mathrm{~nm}$ and detection of emitted fluorescence light at $500 \mathrm{~nm}$ and longer. Optical sections were captured with an image resolution of $1024 \times 1024$ pixels and a distance between sections of less than $400 \mathrm{~nm}$. The resulting image stacks were then further processed using the Open Source image processing package FIJI on a Mac OSX computer (http://fiji.sc/Fiji, Schindelin et al., 2012).

\section{RESULTS/DESCRIPTIONS}

Below we describe six distinct monosulcate, semitectate pollen grains (type I-VI). They are all characterized by reticulate sculpture and columellate connections to an extremely thin nexine. The applied CLSM technique provides detailed images of the surface of the pollen grains and evidence for the structuring of the exine (see Plates I-IV). However, with the applied method it is impossible to differentiate endexine and footlayer. The six pollen types are differentiated based on their size, the development of the reticulum and the shape of the sulcus. So far only a few grains or single specimens are available for each type; for this reason we refrain from describing formal species. Additionally, we describe two pollen grains that we attribute to the genus Afropollis (Afropollis sp. I and II, see Plate IV). They show the characteristic reticulum of this genus, but-as in many Cretaceous forms-the inner wall (nexine) is missing or extremely shrunken.

For comparison and to demonstrate the distinct differences in the optical characteristics we document two pollen grains comparable to the gymnosperm pollen genus Eucommiidites from the same sections (Plate IV , 7, 8, 11, 12, 14, 15). The resolution of the CLSM images shows their homogeneous or slightly granular wall structure, representing a distinct contrast to the exine structure of the columellate, angiosperm-like grains.

Positions on the slides are indicated in England-Finder coordinates.

\section{TYPE I}

Material: 2 specimens; specimen A: Weiach 903.02 m, N38; specimen B: Weiach $901.91 \mathrm{~m}$, T59

Specimen A: Plate I, $(\mathbf{1 - 3 , 5 , 6 )}$; specimen B: Plate I, $(\mathbf{4}, \mathbf{7 - 9})$

Description: Monosulcate, columellate, semitectate, densely reticulate pollen grains

Size: specimen A: $31.5 \times 41.5 \mu \mathrm{m}$; specimen B: $33.0 \times 32.0 \mu \mathrm{m}$

Shape: oval to nearly spherical, compressed

Sulcus: broad open (folded in specimen A) 

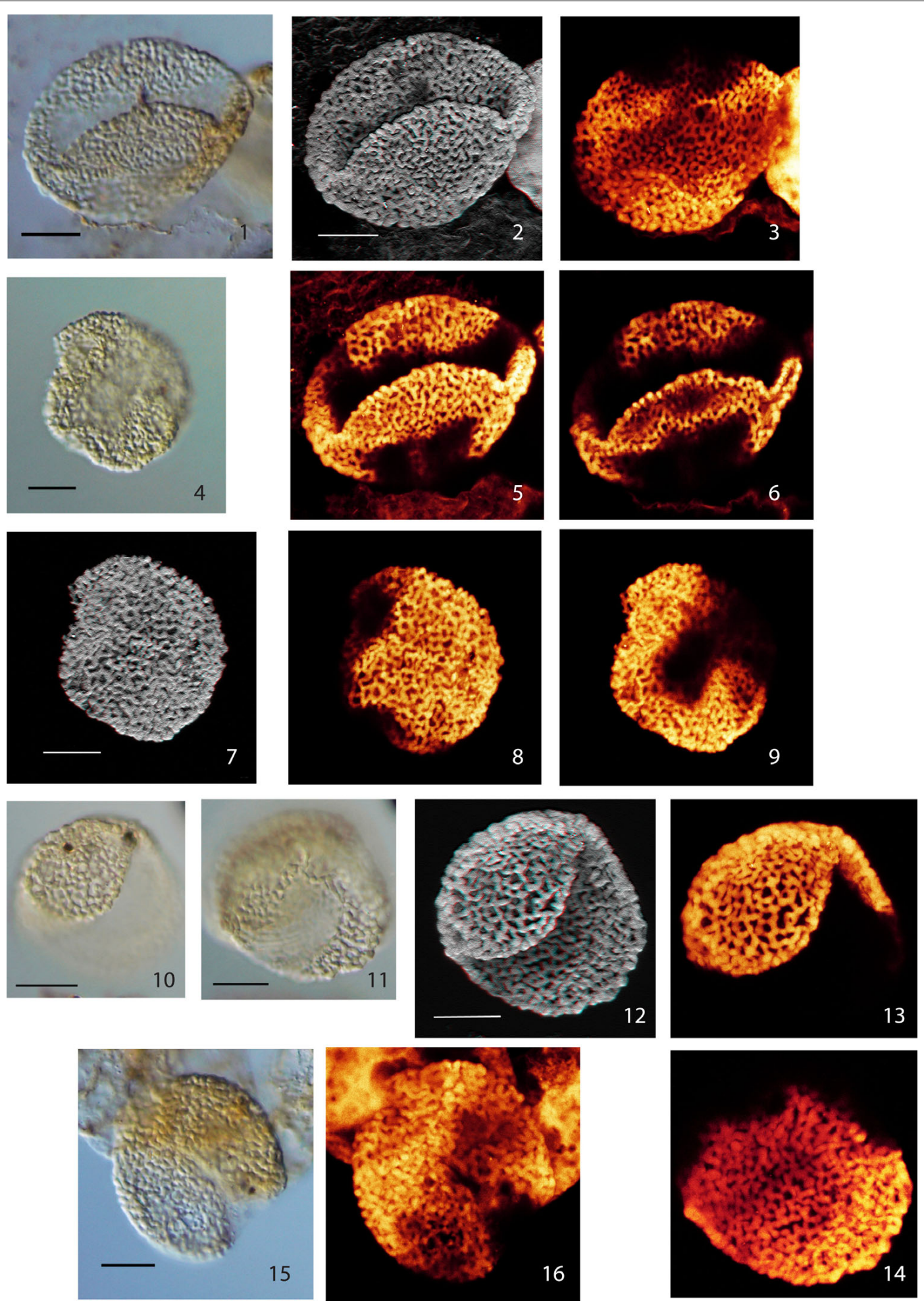

PLATE I | Scale bars: $10 \mu \mathbf{m}$. (1), Pollen Type I, specimen A, LM image (high focus); (2), Pollen Type I, specimen A, CLSM image, total stack

image/projection, anaglyph; (3), Pollen Type I, specimen A, CLSM partial stack image, proximal side; (4), Pollen Type I, specimen B, LM image (median focus); (5), Pollen Type I, specimen A, CLSM partial stack image, distal side; (6), Pollen Type I, specimen A, CLSM single image, optical section; (7), Pollen Type I, specimen B, CLSM total stack image/projection, anaglyph; (8), Pollen Type I, specimen B, CLSM partial stack image, lateral view (high focus); (9),
Pollen Type I, specimen B, CLSM partial stack image, lateral view (low focus): (10), Pollen Type II, specimen A, LM image, high focus; (11), Pollen Type II, specimen A, LM image, low focus; (12), Pollen Type II, specimen A, CLSM total stack image/projection, anaglyph; (13), Pollen Type II, specimen A, CLSM partial stack image, lateral view on distal side (high focus); (14), Pollen Type II, specimen A, CLSM partial stack image, lateral view on proximal side (low focus); (15), Pollen Type II, specimen B, LM image, high focus; (16), Pollen Type II, specimen B, CLSM total stack image/projection. 

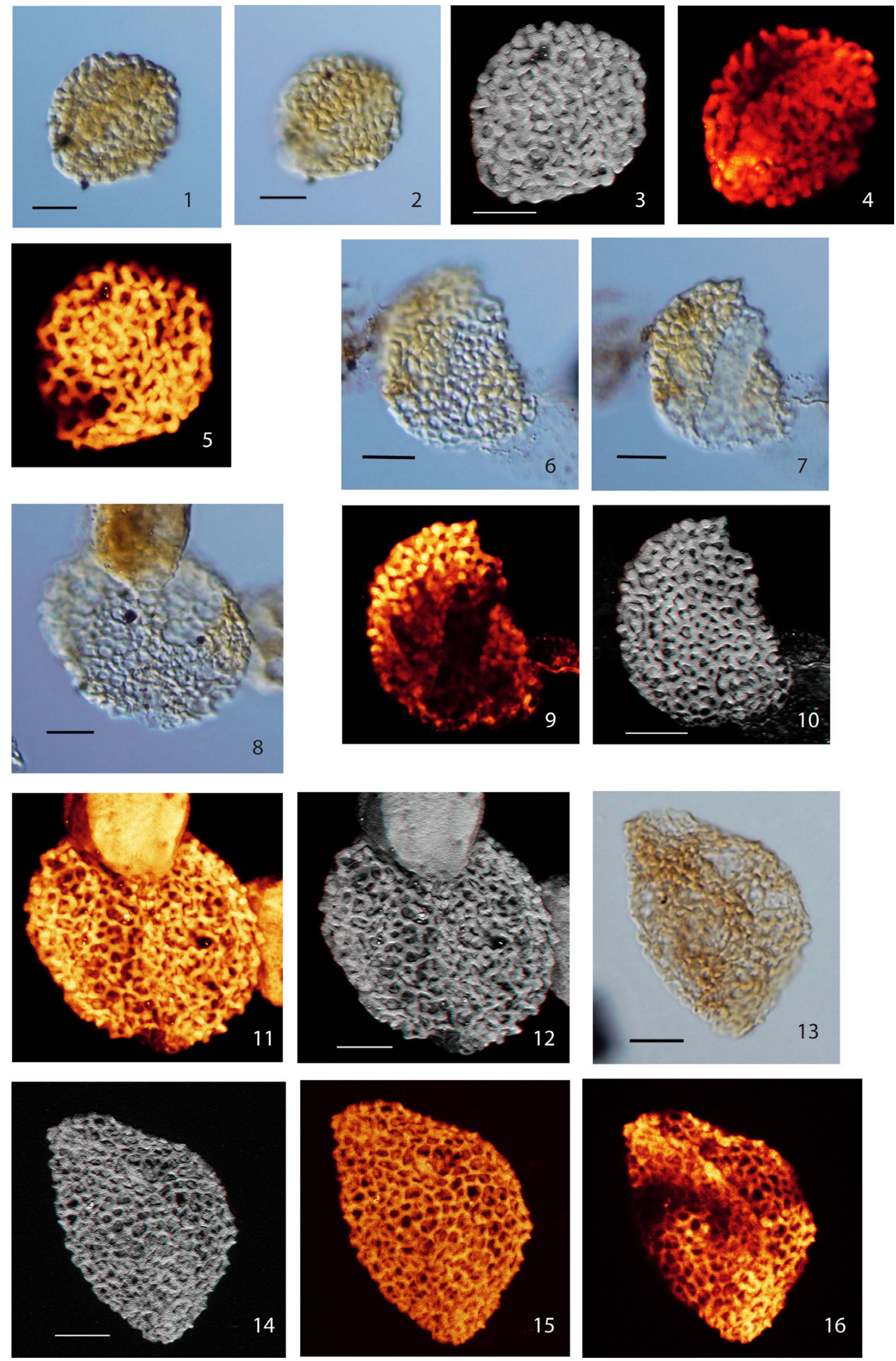
PLATE II | Scale bars: $\mathbf{1 0} \boldsymbol{\mu m}$. (1), Pollen Type III, specimen A, LM image, median focus; (2), Pollen Type III, specimen A, LM image, (high focus); (3), Pollen Type III, specimen A, CLSM total stack image/projection, anaglyph; (4), Pollen Type III, specimen A, CLSM partial stack image, distal side (low focus); (5), Pollen Type III, specimen A, CLSM partial stack image, proximal side (high focus); (6), Pollen Type III, specimen B, LM image (high focus); (7), Pollen Type III, specimen B, LM image (low focus); (8), Pollen Type IV, specimen A, LM image (high focus); (9), Pollen Type III, specimen B, CLSM partial stack image, distal side (low focus); (10) Pollen Type III, specimen B, CLSM total stack image/projection, anaglyph; (11), Pollen Type IV, specimen A, CLSM total stack image/projection; (12), Pollen Type IV, specimen A, CLSM total stack image/projection, anaglyph; (13), Pollen Type IV, specimen B, LM image (median focus); (14) Pollen Type IV, specimen B, CLSM total stack image/projection, anaglyph; (15) Pollen Type IV, specimen B, CLSM total stack image/projection; (16) Pollen Type IV, specimen B, CLSM partial stack image, distal side (median focus).
Wall/structure: ca. $0.7-1.0 \mu \mathrm{m}$ thick; columellae: $0.5-1.5 \mu \mathrm{m}$ (globular); nexine very thin.

Sculpture: reticulate, slightly heterobrochate, smallest meshes near the sulcus and towards the end of the sulcal area. Shape of meshes irregular; mesh size: $0.5-2.0 \mu \mathrm{m}$. Muri: winding, beaded, width $0.5-1.5 \mu \mathrm{m}(-2.0 \mu \mathrm{m}$, columellae head), thickened at the vertices of the reticulum, surface with flat verrucae resulting from the slightly protruding heads of columellae.

\section{TYPE II}

Material: 2 specimens; specimen A: Weiach $903.02 \mathrm{~m}, \mathrm{G} 63 / 3$; specimen B: Weiach $901.91 \mathrm{~m}, \mathrm{~T} 58 / 3$

Specimen A: Plate I, (10-14); specimen B: Plate I, $(\mathbf{1 5}, 16)$

Description: Monosulcate, columellate, semitectate, reticulate pollen grains

Size: specimen A: $30.0 \times 32.0 \mu \mathrm{m} /$ specimen B: $30.0 \times 35.0 \mu \mathrm{m}$

Shape: spherical, compressed

Sulcus: short open slit (see Type I)

Wall/structure: $0.5-1.0 \mu \mathrm{m}$ thick $(-1.5 \mu \mathrm{m}$, head of columellae), columellate. Columellae club-shaped to almost spherical $(0.6-1.5 \mu \mathrm{m})$ arranged in a reticulate pattern, reduced in size toward the sulcus (Plate I, 11, 12); nexine very thin.

Sculpture: irregularly reticulate, heterobrochate, meshes with irregular shape and size; size: $0.5-3.5 \mu \mathrm{m}$. Muri: consisting of columellae arranged in a reticulate pattern; width $0.5-2.5 \mu \mathrm{m}$ (head of columellae); slightly beaded, surface with flat verrucae (protruding heads of columellae).

\section{TYPE III}

Material: 2 specimens; specimen A: Weiach $901.91 \mathrm{~m}, \mathrm{Q} 37 / 4$; specimen B: Weiach $901.91 \mathrm{~m}, \mathrm{U} 64 / 2$

Specimen A: Plate II, (1-5); specimen B: Plate II, (6, 7, 9, 10)

Description: Monosulcate, columellate, semitectate, reticulate pollen grains

Size: $28.0 \times 32.0 \mu \mathrm{m} / 26 \times 35.0 \mu \mathrm{m}$

Shape: spherical to ellipsoidal, compressed

Sulcus: slit-like or broad, open

Wall/structure: $0.5-2.0 \mu \mathrm{m}$ thick, columellate; columellae clubshaped to nearly globular, most pronounced at the vertices of the muri; nexine very thin.

Sculpture: reticulate, heterobrochate; reticulum finer towards sulcus; meshes mostly roundish, mesh size $0.8-3.2 \mu \mathrm{m}$. Muri: coarse, width: (0.5-) 1.0-1.5 $\mu \mathrm{m}$; surface verrucate as a result of protruding heads of columellae.

\section{TYPE IV}

Material: 2 specimens; specimen A: Weiach $901.91 \mathrm{~m}, \mathrm{~J} 40 / 3$; specimen B: Weiach $950.82 \mathrm{~m}, \mathrm{~V} 55 / 1$
Specimen A: Plate II, $(\mathbf{8}, \mathbf{1 1}, \mathbf{1 2})$; specimen B, Plate II, (13-16) Description: Monosulcate, columellate, semitectate, reticulate, heterobrochate pollen grains

Size: specimen A: $40 \times 47.0 \mu \mathrm{m} /$ specimen B: $32.0 \times 46.0 \mu \mathrm{m}$

Shape: spherical-ellipsoidal, compressed

Sulcus: slit-like, elongate, narrow

Wall/structure: $2.0 \mu \mathrm{m}$ thick, columellate, columellae: ca. $2.0 \mu \mathrm{m}$, nearly spherical, head diameter: $1.0-2.2 \mu \mathrm{m}$; nexine very thin. Sculpture: reticulate, heterobrochate, reduced lumina near the sulcus; lumina mostly roundish; mesh size: $1.0-3.0 \mu \mathrm{m}$. Muri: width $0.5-1.5 \mu \mathrm{m}$ (max. $2.2 \mu \mathrm{m}$, head of columellae), vertices slightly thickened; surface: verrucate resulting from protruding heads of columellae at the vertices of the reticulum.

\section{TYPE V}

Material: 3 specimens; specimen A: Weiach $901.91 \mathrm{~m}, \mathrm{G} 53$; specimen B: Weiach 903.02 m, M52/1; specimen C: Weiach $901.91 \mathrm{~m}$, $\mathrm{H} 40 / 1$

Plate III, (1-5) (specimen A); Plate III, (6-9, 11) (specimen B); Plate III, $(10,12,13)$ (specimen C)

Description: Monosulcate, columellate, semitectate, finely reticulate to perforate pollen grains

Size: specimen A: $34.0 \times 41.0 \mu \mathrm{m}$, specimen B: $29 \times 36 \mu \mathrm{m}$, specimen C: $27.0 \times 42.0 \mu \mathrm{m}$

Shape: nearly spherical-ellipsoidal (boat shaped), compressed

Sulcus: round-broad elongate, open

Wall/structure: $0.5-1.0 \mu \mathrm{m}$ ( $-1.3 \mu \mathrm{m}$ including columellae); columellate, columellae nearly spherical-club-shaped: $0.5-1.3 \mu \mathrm{m}$ high, head diameter: $0.5-1.5,0.2 \mu \mathrm{m}$ near sulcus; nexine very thin.

Sculpture: reticulate, heterobrochate, mesh size reduced to perforate toward sulcus; mesh size: $1.2-2.4 \mu \mathrm{m}$ (proximal); $0.2-1.9 \mu \mathrm{m}$ (distal). Muri forming a reticulate pattern; width: $0.5-1.0 \mu \mathrm{m}(0.3$ um distally and $1.5 \mu \mathrm{m}$ at max. head diameter); surface verrucate formed by prominent columellae heads.

\section{TYPE VI}

Material: 1 specimen: Weiach 905.99 m, Y49/1

Plate IV, (1-4)

Description: Monosulcate, columellate, finely irregularly reticulate pollen grain

Size: $22.0 \times 34.0 \mu \mathrm{m}$

Shape: ellipsoidal, boat shaped, compressed

Sulcus: narrow slit?

Wall/structure: $0.5 \mu \mathrm{m}$ thick, semi-intectate, columellate. Tectum is reduced to few connections between the columellae. Columellae roundish to club-shaped, $0.5-0.8 \mu \mathrm{m}$ high; nexine very thin. 

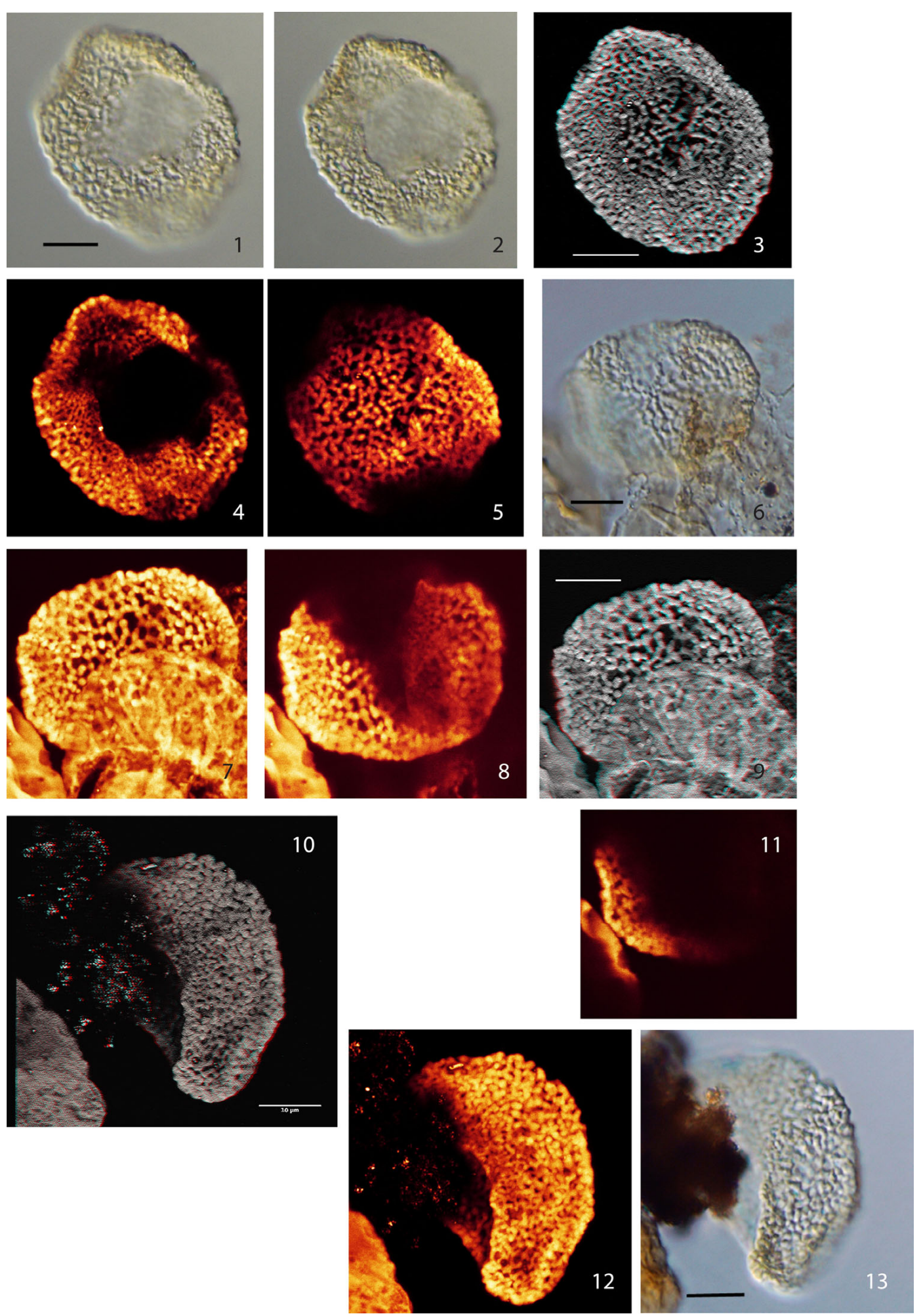

PLATE III | Scale bars: $\mathbf{1 0} \mu \mathbf{m}$. (1), Pollen Type V, specimen A, LM image (median focus); (2), Pollen Type V, specimen A, LM image (high focus); (3) Pollen Type V, specimen A, CLSM total stack image/projection, anaglyph; (4) Pollen Type V, specimen A, CLSM partial stack image, distal side (high focus); (5) Pollen Type V, specimen A, CLSM partial stack image, proximal side (low focus); (6) Pollen Type V, specimen B, LM image (high focus); (7) Pollen Type V, specimen B, CLSM total stack image/projection; (8) Pollen Type V, specimen B, CLSM partial stack image, lateral view on distal side (low focus): (9) Pollen Type V, specimen B, CLSM total stack image/projection, anaglyph; (10) Pollen Type V, specimen C, CLSM total stack image/projection, anaglyph, lateral view; (11), Pollen Type V, specimen B, CLSM single image, optical section; (12), Pollen Type $V$, specimen C, CLSM total stack image/projection, lateral view; (13), Pollen Type V, specimen C, LM image, lateral view (high focus). 

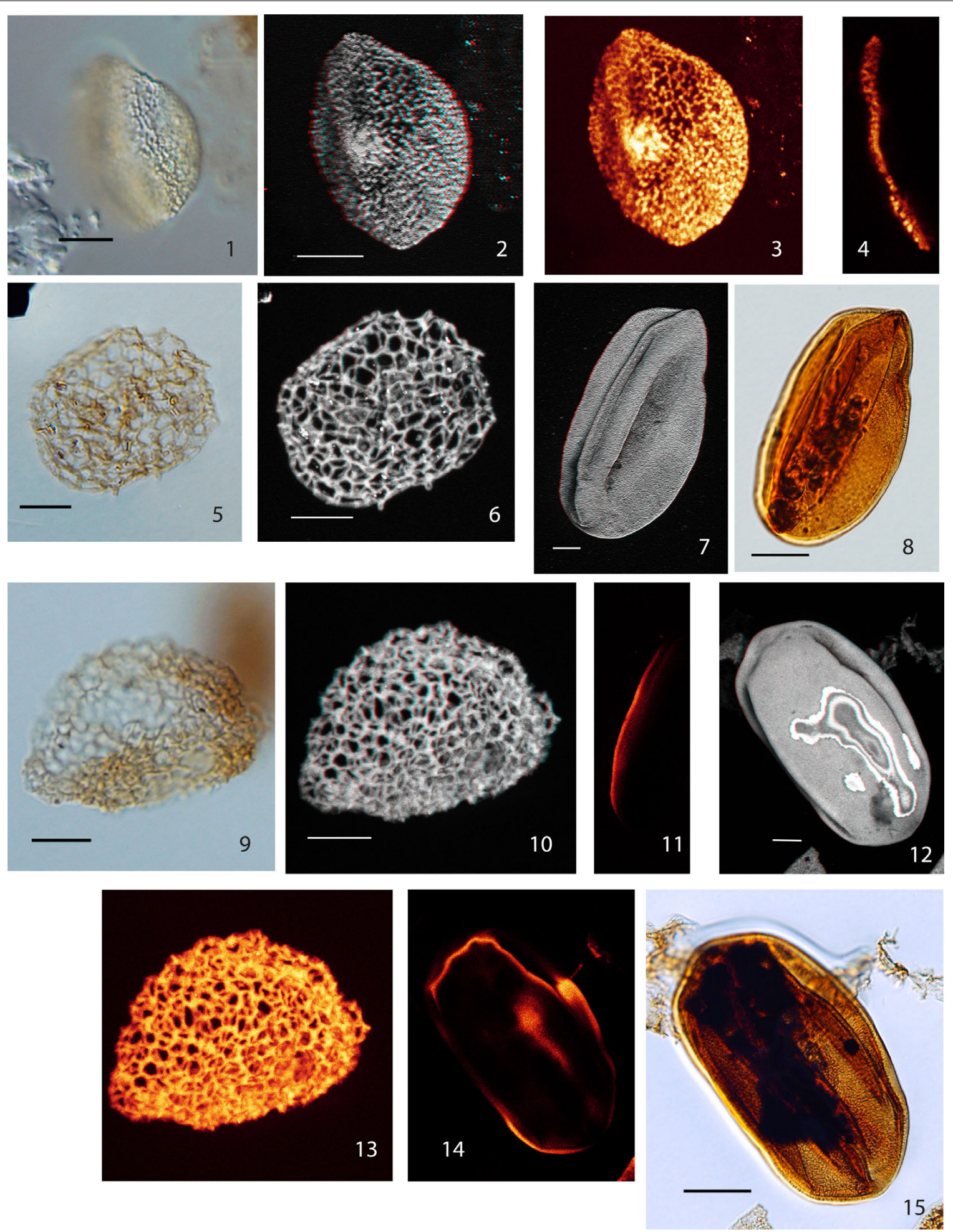

PLATE IV | Scale bars: $\mathbf{1 0} \boldsymbol{\mu \mathbf { m }}$, except (8) and (15) $(20 \mu \mathrm{m})$; (1) Pollen Type VI, LM image (high focus); (2) Pollen Type VI, CLSM total stack image/projection, anaglyph; (3), Pollen Type VI, CLSM total stack image/projection; (4), Pollen Type VI, CLSM single image, optical section; (5), Afropollis sp. I, LM image (median focus); (6) Afropollis sp. I, CLSM total stack image/projection, anaglyph; (7) Eucommiidites sp. 1, CLSM total stack image/projection, anaglyph; (8), Eucommiidites sp. 1, LM image (median focus); (9) Afropollis sp. II, LM image, high focus; (10), Afropollis sp. II, CLSM total stack image/projection, anaglyph; (11), Eucommiidites sp. 1, CLSM single image, optical section; (12), Eucommiidites sp. 2, CLSM total stack image/projection, anaglyph; (13), Afropollis sp. II, CLSM total stack image/projection; (14), Eucommiidites sp. 2, CLSM single image, optical section; (15), Eucommiidites sp. 2, LM image (median focus). 
Sculpture: fine, irregularly reticulate pattern. Mesh size 0.5-1.8 $\mu \mathrm{m}$. Muri: $0.3-0.6 \mu \mathrm{m}$ wide (columellae heads $-0.8 \mu \mathrm{m}$ ); surface finely verrucate resulting from the protruding ends of columellae.

\section{Afropollis sp. I \\ Material: 1 specimen: Weiach $950.82 \mathrm{~m}, \mathrm{U} 53 / 4$ \\ Plate IV, $(5,6)$ \\ Description: Monosulcate/inaperturate, coarsely reticulate pollen grain. \\ Size: $44.0 \times 30.0 \mu \mathrm{m}$ \\ Shape: ellipsoidal, compressed, probably in lateral view \\ Sulcus: not observed \\ Wall/structure: only sexine recognizable, nexine-if present- thin and detached; \\ Sculpture: Reticulum heterobrochate, lumina roundish to polygonal, mesh size: $1.0-3.5 \mu \mathrm{m}$; columellae not visible. Muri higher than wide, width ca. $0.5 \mu \mathrm{m}$, ca. $1.0 \mu \mathrm{m}$ high, with radial elements; surface echinate to verrucate as a result of radially protruding elements. Afropollis sp. I differs from Afropollis sp. II and from most of the species described from the Cretaceous in having more regular (not sinuous) muri.}

\section{Afropollis sp. II \\ Material: 1 specimen: Leuggern 171.63 m, R55 \\ Plate IV, $(9,10,13)$ \\ Description: Inaperturate, reticulate pollen grain}

Shape: spherical, compressed, slightly folded and partly broken.

Size: $37.0 \times 32.0 \mu \mathrm{m}$

Sulcus: not observed

Wall/structure: only sexine recognizable, nexine-if presentthin and detached.

Reticulum: homobrochate, lumina polygonal- roundish, and slightly protruding elements at the vertices of the reticulum, mesh size: $2.0-4.5 \mu \mathrm{m}$. Muri: partly sinuous, ca. $0.5 \mu \mathrm{m}$ wide, $0.5-1.5 \mu \mathrm{m}$ high, with dispersed radial elements, some of them few protruding.

This pollen grain resembles those reported as type $G$ by Hochuli and Feist-Burkhardt (2004). However, on pollen Type G the radial elements are poorly expressed; for this reason it was not assigned to Afropollis.

\section{GYMNOSPERM POLLEN \\ Eucommiidites sp. 1}

Material: Weiach $980.57 \mathrm{~m}, \mathrm{O} 59 / 1$

Plate IV, (7-8, 11)

Eucommiidites sp. 1 has a granulate surface. The wall is densely granulate.

Size: $92 \times 47 \mu \mathrm{m}$

\section{Eucommiidites sp. 2}

Material: Weiach $978.47 \mathrm{~m}$; J52/2

Plate IV, (12, 14-15)

Size: $90 \times 50 \mu \mathrm{m}$

\section{DISCUSSION-CRETACEOUS AND PRE-CRETACEOUS RECORDS}

Pollen grains are easily dispersed over wide areas due to their relatively small size and the high numbers produced. They can be found in various depositional environments (marine, coastal, and terrestrial). For this reason records of fossil pollen are most complete if compared to other plant organs such as seeds or leaves. Generally accepted first records of angiosperm pollen are mentioned from the early part of the Early Cretaceous (Valanginian-early Hauterivian), corresponding to an age range of approximately 139-133 Ma. However, within this interval they are extremely rare and poorly documented. Most palynological records from the basal Cretaceous (Berriasian-Valanginian) lack angiosperm pollen (e.g., Norris, 1969; Dörhöfer, 1977; Dörhöfer and Norris, 1977; Doyle, 1983; Regali and Viana, 1989; Hughes, 1994; El Albani et al., 2004; Kujau et al., 2013).

Most angiosperm pollen grains recorded from the earlier part of the Early Cretaceous (Valanginian/Hauterivian) are small, monosulcate or sometimes trichotomosulcate, finely reticulate to perforate, and show a distinct columellate structure. The genus Clavatipollenites and the species $C$. hughesii are among the most frequently mentioned taxa from this interval (e.g., Doyle, 1969; Gübeli et al., 1984; Burger, 1990, 1996; Trincão, 1990). One of the commonly cited records apparently includes several well-preserved angiosperm pollen grains reported from the Valanginian/Hauterivian of Italy. However, this record is documented only in an abstract without illustrations (Trevisan, 1988). Brenner (1996) published several finds from the Helez Formation of Israel of a probable Valanginian to Hauterivian age. However, the preservation of the figured specimens (Brenner, 1996, Figures $5.4 \mathrm{~A}-\mathrm{D})$ is too poor to support an angiosperm affinity; hence, Brenner's statement that the first angiosperms were represented by inaperturate grains cannot be corroborated. Some of the early records of angiosperm pollen are limited to the genus Clavatipollenites. A stratigraphically well constrained record exists for C. hughesii for the Valanginian of Morocco, where this form co-occurs with age-diagnostic dinoflagellate cysts, e.g., Biorbifera johnewingii and Druggidium spp. (Gübeli et al., 1984).

Based on the distribution of angiosperm pollen Hughes (1994) defined five phases for the palynological record of the Wealden of Southern England. The oldest phase (phase 0, Hauterivian) contains few angiosperm pollen grains; one of them might be assigned to the genus Clavatipollenites [Palaeotaxon Hauterivian-microtect of Hughes (1994)], another represents a tectate form with verrucate surface [Palaeotaxon Hauteriviancactisulc of Hughes (1994)] and a third one is coarsely reticulate [Palaeotaxon-lacebee of Hughes (1994)]. Phase 1, probably of late Hauterivian age, includes a considerable number of monosulcate, reticulate morphotypes. Most of these grains [Retisulc group of Hughes (1994)] seem to fall in the morphological range of the Retimonocolpites complex or could be assigned to Clavatipollenites or Tucanopollis morphotypes [Palaeotaxon Barremian-ring of Hughes (1994)]. The increase in diversity of the angiosperm pollen between phase 0 and phase 1 -taking place during the Hauterivian-is remarkable; it implies a considerable diversification within approximately $3.5 \mathrm{Ma}$ or else it represents a wave of immigration from other areas. Additionally, Barremian pollen records suggest an already wide distribution of the angiosperms, including Gondwana with Africa (e.g., Doyle et al., 1977; Schrank and Mahmoud, 2002), South America (e.g., Regali and Viana, 1989) and Australia (e.g., Burger, 1990, 1996); Laurasia with North America (Burden, 1984), Europe (e.g., Hughes, 1994; 
Heimhofer et al., 2007), Eastern Russia (Markevitch, 1994) and China (e.g., Wang, 2000; Zhou et al., 2009); and show a considerable diversity and abundance in some areas (e.g., Egypt, Schrank and Mahmoud, 2002), (for additional references see also Eklund et al., 2004)

Based on close morphological similarities Clavatipollenites has been associated with the family of Chloranthaceae-namely with Ascarina (Couper, 1960; Doyle, 1969; Walker and Walker, 1984; Endress, 1987; Eklund et al., 2004). However, based on the detailed study of Hughes (1994) it seems that pollen grains determined as Clavatipollenites have to be regarded as a heterogeneous entity, probably including several groups of various affinity, e.g., Chloranthaceae, and probably related extinct groups (Pedersen et al., 1991) as well as Austrobaileyales (Endress and Honegger, 1980) thus including some representatives of the most basal families of the ANITA grade (including Amborella, Nymphaeales, Illiciales, Trimenia, and Austrobaileyales). However, Clavatipollenites represents the most commonly recorded pollen from the earlier part of the Early Cretaceous (Valanginian - early Hauterivian). Doyle (2012) suggested that these pollen grains represent the first angiosperm crown group fossils. So far the basal angiosperms of the ANITA grade are poorly represented in the early angiosperm pollen records. Most of these plants produce columellate and tectate pollen (Doyle, 2012). One possible early record from the early Hauterivian is represented by the tectate angiosperm pollen reported as Palaeotaxon Hauterivian-cactisulc (Hughes, 1994), which shows some resemblance with the pollen of Amborella. However, the majority of the pollen grains from the earlier part of the Lower Cretaceous (pre-Aptian) are semitectate and commonly show a well-developed reticulum. According to Doyle (2012) semitectate conditions with a distinctly reticulate sexine arose at the node connecting Austrobaileyales and mesangiosperms.

Evidence for pre-Cretaceous presence of angiosperms is difficult to assess. Some finds from the Jurassic announced with much public attention proved to be based on wrong ages (Sun et al., 1998; He et al., 2004, 2006) and the interpretations of other remains from the Jurassic (e.g., Schmeissneria) are controversial (Wang et al., 2007; van Konijnenburg-van Cittert et al., 2010; Wang, 2010; Friis et al., 2011; Doyle, 2012). Angiosperm-like pollen finds from this period are rare or questionable; the pollen reported from the Oxfordian of France (Cornet and Habib, 1992) are regarded here as contamination (see also Friis et al., 2011). Clavatipollenites has been repeatedly reported from the Jurassic (e.g., Pocock, 1962, 1970; Schulz, 1967; Vigran and Thusu, 1975; Abbink, 1998). For at least some of these grains Doyle et al. (1975) and Batten and Dutta (1997) proved a clear gymnospermous affinity. However, in routine palynological studies it might be difficult to distinguish small monosulcate grains with distinct angiospermous columellate structure from those with a clearly gymnospermous spongy alveolar structure.

Triassic records of angiosperms or angiosperm-like plants are discussed since the discovery of the famous leaf remains described as Sanmiguelia (Brown, 1956). Subsequent discoveries of reproductive structures of this plant and of angiosperm-like pollen in Late Triassic sediments nourished the debate about a
Triassic origin of the group (Cornet, 1977, 1986, 1989a,b). Despite considerable attention the interpretation and attribution of the leaves and the reproductive structures (Axelrodia) of Sanmiguelia remain ambiguous (Friis et al., 2011; Doyle, 2012). Whereas some authors considered it as an angiosperm (Brown, 1956; Cornet, 1986, 1989a) others suggested an attribution to Ginkgophytes and rejected a possible relation to angiosperms (Crane, 1987; Doyle and Donoghue, 1993). Pollen grains associated with male organs show clear gymnospermous features. Recently, Doyle (2012) proposed that Sanmiguelia might represent a plant attached to the stem lineage of the angiosperms or a gymnosperm without closer relationship to angiosperms.

The affinity of the pollen group described as Crinopolles (including the genera Tricrinopollis, Monocrinopollis, Dicrinopollis, and Zonacrinopollis) from the Late Triassic (Carnian) of Virginia (Cornet, 1989b) continues to be a subject of controversy (e.g., Zavada, 2007; Friis et al., 2011; Doyle, 2012). These pollen grains show some clear angiospermous features (Cornet, 1989b); they are monosulcate and have a semitectate (reticulate) outer wall, which is connected by columellae to the inner wall (nexine). Other features, like the uniformly thick endexine, are more gymnosperm-like (Doyle and Hotton, 1991). Recently, it has been suggested that the Crinopolles group may represent plants on the angiosperm stem lineage (Doyle and Hotton, 1991; Doyle and Donoghue, 1993; Doyle, 2012). Since its original description this pollen group has been reported only sporadically (e.g., Litwin and Ash, 1993); it seems that its parent plants had an either temporally or regionally restricted distribution. Cornetipollis reticulata is another interesting pollen type from the Late Triassic that shows all the essential characteristics of angiosperm pollen (Pocock and Vasanthy, 1988). It is characterized by numerous exinal bands that are semitectate (reticulate and perforate) and are connected to the very thin inner layer (nexine) by columellae.

Middle Triassic angiosperm-like pollen grains have been published from drill cores from the Norwegian Barents Sea (Hochuli and Feist-Burkhardt, 2004). Previously these forms were repeatedly reported as Retisulcites sp. 1 and sp. 2 from Anisian and Ladinian sediments of exploration wells and well-calibrated cores (Hochuli et al., 1989; Vigran et al., 1998). Hochuli and FeistBurkhardt (2004) attributed these pollen grains to angiosperms or to a new, unknown group of gymnosperms. These findings have received rather mixed attention. Despite distinct morphological differences (e.g., very thin nexine) Doyle (2012) associated them with the Crinopolles group. Other authors accepted them as clear evidence for angiosperms (Zavada, 2007; Clarke et al., 2011), or as interesting evidence to consider (Taylor et al., 2009), whereas others questioned the attribution to angiosperms (Maheshwari, 2007) or simply ignored them (Friis et al., 2011).

The pollen grains here described add to the considerable diversity already documented from the Middle Triassic of the Barents Sea (Hochuli and Feist-Burkhardt, 2004). In the Barents Sea they were found in palynological assemblages with high representation of spores reflecting rather humid environments (Hochuli and Vigran, 2010). During the Anisian the sections from Northern Switzerland were located about $20^{\circ} \mathrm{N}$. The angiosperm-like 
pollen grains come from an interval consisting of evaporites with intercalated thin layers of sand and siltstones. Here, the lithology as well as the associated palynofloras, characterized by pronounced dominance of the Triadispora group, known to represent xerophytic elements (Kürschner and Herngreen, 2010), as well as the scarcity of spores, suggest a dry climate for this interval.

Representatives of the Afropollis group are common elements of Cretaceous low latitudinal spore-pollen assemblages. Originally described by Doyle et al. (1982) as early angiosperm pollen and showing some angiospermous features, they are still considered as such by many authors (e.g., Krassilov and Schrank, 2011; Coiffard et al., 2012). Their attribution to angiosperms was called into question by the discovery of an (unpaired) pollen sac containing in situ Afropollis (Friis et al., 2011). Consequently, we consider them here as representatives of a so far unknown group of gymnosperms with singular pollen morphology. The known stratigraphic range of the Afropollis group covers the interval between the Barremian (e.g., Penny, 1989; Schrank and Mahmoud, 2002) and the middle Cenomanian (e.g., Schrank and Ibrahim, 1995). Its main distribution lies between the late Barremian or early Aptian and the lower Cenomanian (Doyle et al., 1982; Doyle, 1992). Thus, similar to the angiosperms, our record of this group from the Middle Triassic opens another observation gap of over $100 \mathrm{Ma}$.

\section{CONCLUSIONS}

Assessing the appearance of the angiosperms by fossil pollen grains is a rather difficult issue. However, according to Zavada (1984a) the combined characteristics of the described pollen (small, monosulcate, columellate, semitectate-reticulate) grains exhibit a full inventory of angiosperm pollen synapomorphies and probably also express the corresponding function, e.g., selfincompatibility (Zavada, 1984b). However, according to Doyle (2012) the early appearance of columellate reticulate pollen poses a problem for connecting them with the stem lineage or the most basal crown lineages. Based on molecular data the basal groups of angiosperms produce pollen grains with a continuous tectum and the semitectate, reticulate conditions developed at the node connecting Austrobaileyales and mesangiosperms.

Interpretation of the molecular evidence for the origin of flowering plants is controversial depending on the data and the calculation methods. Estimates for the origin of flowering plants range from the late Early Permian (275 Ma) to the Late Triassic (221.5 Ma) or Early Jurassic (193.8 Ma) (Magallón, 2010; Magallón et al., 2013). Other authors suggest a Late Triassic age (228-217 Ma) (Smith et al., 2010) or give a Jurassic age range (183-147 Ma) (Bell et al., 2010). Thus there are some calculations that would corroborate the first fossil evidence from the Middle Triassic.

If we accepted the monosulcate pollen from the Middle and Late Triassic as evidence for a pre-Cretaceous origin of crown group angiosperms the lack of fossil records throughout the Jurassic would remain difficult to explain. Some authors gave ecological reasons for this gap, such as that the early angiosperms evolved in upland environments, far from the potential sedimentary basins (Axelrod, 1952, 1970). From the present distribution and the physiology of extant basal angiosperms Feild et al. (2004, 2009) concluded that their ancestors must have lived in dark, wet and disturbed understory habitats. The possibly rare occurrences of such habitats in the Jurassic were used to explain the lack of fossil records. However, if the Triassic angiosperm-like pollen grains would represent an angiosperm crown group our evidence that they lived in a wide range of habitats, including arid environments, would contradict the hypothesis that early crown group angiosperms were restricted to wet understory habitats (Feild et al., 2004, 2009) and would make it still more difficult to explain the Jurassic gap in their record.

Compared to the early records in the Cretaceous (Valanginian-early Hauterivian) the diversity of the pollen grains described from the Triassic is rather high and their occurrence in different environments also suggests a high adaptability. Additionally, their morphology appears to be closer to the Cretaceous morphotypes of Retimonocolpites, thus to the phases 1-4 of the morphological succession of Hughes (1994), implying that there is no evident relationship between the pollen grains known from the Middle Triassic and the oldest Cretaceous angiosperm pollen (phase 0 of Hughes, 1994). Considering the hundred million year gap in the record as well as morphological differences to the earliest Cretaceous we suggest that these pollen grains most likely represent stem relatives of the angiosperms. Thus, the monosulcate, columellate conditions of the pollen might represent an ancestral feature, expressed at different stages in the evolution of the flowering plants, or alternatively, these features would represent analogues and were independently developed by an unrelated, and so far unknown, group of gymnosperms. However, since this group produced a wide variety of monosulcate and reticulate-thus angiosperm-like-pollen grains and could adapt to various environments, we expect that they may be found in other areas and in other stratigraphic and environmental contexts. As for the Afropollis group we have to await discoveries of the corresponding megafossils to learn more about the morphology and relationship of the parent plants of the pollen grains here described.

\section{ACKNOWLEDGMENTS}

We thank D. Rebetez (University Bern) for providing us with an up-dated stratigraphic column and E. Schneebeli (University Zürich) and U. Heimhofer (University of Hannover) for comments on an earlier version of this report. We are grateful for the very careful review and thoughtful comments of J.A. Doyle (University of California) as well as for the helpful reviews of E. Kustatscher (Naturmuseum Südtirol), L. Mao (Chinese Academy of Sciences), and M. S. Zavada (East Tennessee State University). NAGRA, the National Cooperative for the Disposal of Radioactive Waste, Wettingen, Switzerland, is acknowledged for giving us access to the studied drill cores. CLSM studies have been carried out at the facilities of the Biology Department of Technische Universität Darmstadt, Germany. We are very grateful to $\mathrm{T}$. Meckel (TU Darmstadt) for providing access and giving helpful advice. 


\section{REFERENCES}

Abbink, O. A. (1998). Palynological Investigations in the Jurassic of the North Sea Region. Ph.D. thesis. Utrecht: Universiteit Utrecht, 192.

Axelrod, D. I. (1952). A theory of angiosperm evolution. Evolution 6, 29-60. doi: 10.2307/2405502

Axelrod, D. I. (1970). Mesozoic paleogeography and early angiosperm history. Bot. Rev. 36, 277-319. doi: 10.1007/BF02858880

Batten, D. J., and Dutta, R. J. (1997) Ultrastructure of exine of gymnospermous pollen grains from the Jurassic and basal Cretaceous in Northwest Europe and implications for botanical relationships. Rev. Palaeobot. Palynol. 99, 25-45. doi: 10.1016/S0034-666700036-5

Bell, C. D., Soltis, D. E., and Soltis, P. S. (2010). The age and diversification of the angiosperms rerevisited. Am. J. Bot. 97, 1296-1303. doi: 10.3732/ajb.0900346

Brenner, G. J. (1996). "Evidence for the earliest stage of angiosperm pollen evolution: a paleoequatorial section from Israel," in Flowering Plant Origin, Evolution and Phylogeny, eds D. W. Taylor and L. J. Hickey (New York, NY: Chapman and Hall), 91-115. doi: 10.1007/978-0585-23095-5_5

Brown, R. W. (1956). Palmlike plants from the Dolores Formation (Triassic) in southwestern Colorado. US Geol. Surv. Prof. Pap. 274H, 205-209.

Burger, D. (1990). Early angiosperms from Queensland, Australia. Rev. Palaeobot. Palynol. 65, 153-161. doi: 10.1016/0034-6667(90)90066-R

Burger, D. (1996). Mesozoic palynomorphs from the North West Shelf, offshore Western Australia. Palynology 20, 49-103. doi: 10.1080/01916122.1996.9989470

Burden, E. T. (1984). “Terrestrial palynomorph biostratigraphy of the lower part of the Mannville Group (Lower Cretaceous) Alberta and Montana," in The Mesozoic of Middle North America, Vol. 9, eds D. F. Stott and D. J. Glass (Calgary, AB: Canadian Society of Petroleum Geologists), 249-269.

Coiffard, C., Gomez, B., DavieroGomez, V., and Dilcher, D. L. (2012). Rise to dominance of angiosperm pioneers in European Cretaceous environments. Proc. Natl. Acad. Sci. U.S.A. 109, 20955-20959. doi: 10.1073/pnas. 1218633110

Clarke, J. T., Warnock, R. C. M., and Donoghue, P. C. J. (2011). Establishing a time-scale for plant evolution. New Phytol. 1-36. doi: 10.1111/j.1469-8137.2011.03794.x

Cornet, B. (1977). "Angiosperm-like pollen with tectate-columellate wall structure from the Upper Triassic (and Jurassic) of the Newark Supergroup, USA," in American Association of Stratigraphic Palynologists 10th Annual Meeting, (Tulsa), Abstracts, 8-9.

Cornet, B. (1986). The leaf venation and reproductive structures of a Late Triassic angiosperm, Sanmiguelia lewisii. Evol. Theory 7, 231-309.

Cornet, B. (1989a). The reproductive morphology and biology of Sanmiguelia lewisii, and its bearing on angiosperm evolution in the Late Triassic. Evol. Trends Plants 3, 25-51.

Cornet, B. (1989b). Late Triassic angiosperm-like pollen from the Richmond Rift Basin of Virginia, U.S.A. Palaeontographica Abt. B 213, 37-87.

Cornet, B. (1996). "A new gnetophyte from the Late Carnian (Late Triassic) of Texas and its bearing on the origin of the angiosperm carpel and stamen," in Flowering Plant Origin, Evolution and Phylogeny, ed D. W. Taylor and L. J. Hickey (New York, NY: Chapman and Hall), 32-67. doi: 10.1007/978-0585-23095-5_3

Cornet, B., and Habib, D. (1992). Angiosperm-like pollen from the ammonite-dated Oxfordian (Upper Jurassic) of France. Rev. Palaeobot. Palynol. 71, 269-294. doi: 10.1016/0034-666790167-F

Couper, R. A. (1960). New Zealand Mesozoic and Cainozoic plant microfossils. N.Z. Geol. Surv. Palaeontol. Bull. 32, 1-87.

Crane, P. R. (1987). Review of Cornet 1986. Evol. Theory 7, 231-309.

Crane, P. R., and Lidgard, S. (1989). Angiosperm diversification and palaeolatitudinal gradients in Cretaceous floristic diversity. Science 246, 675-678. doi: 10.1126/science.246.4930.675

Dörhöfer, G. (1977). Palynologie und Stratigraphie der BückebergerFormation (BerriasiumValanginium) in der Hilsmulde (NW-Deutschland). Geol. Jb. A 42, 3-122.

Dörhöfer, G., and Norris, G. (1977). Discrimination and correlation of highest Jurassic and lowest Cretaceous terrestrial palynofloras in north-west Europe. Palynology 1, 79-93. doi: 10.1080/01916122.1977. 9989151
Doyle, J. A. (1969). Cretaceous angiosperm pollen of the Atlantic Coastal Plain and its evolutionary significance. J. Arnold Arbor. 50, $1-35$.

Doyle, J. A. (1983). Evidence for Berriasian age of basal Potomac Group sediments, Crisfield well, eastern Maryland. Pollen Spores 25 499-530.

Doyle, J. A. (1992). Revised palynological correlations of the lower Potomac Group (USA) and the Cocobeach sequence of Gabon (Barremian-Aptian). Cretac. Res. 13, 337-349. doi: 10.1016/0195667190039-S

Doyle, J. A. (2012). Molecular and fossil evidence on the origin of angiosperms. Annu. Rev. Earth Planet. Sci. 40, 301-326. doi 10.1146/annurev-earth-042711-105 313

Doyle, J. A., and Donoghue, M. J. (1993). Phylogenies and angiosperm diversification. Paleobiology 19, 141-167.

Doyle, J. A., and Hotton, C. L. (1991). "Diversification of early angiosperm pollen in a cladistic context," in Pollen and Spores: Patterns of Diversification, eds S. Blackmore and S. H. Barnes (Oxford: Clarendon), 169-195.

Doyle, J. A., Van Campo, M., Lugardon, B. (1975). Observations on exine structure of Eucommiidites and Lower Cretaceous angiosperm pollen. Pollen Spores 17, 429-486.

Doyle, J. A., Biens, P., Doerenkamp, A., and Jardiné, S. (1977). Angiosperm pollen from the pre-Albian Lower Cretaceous of equatorial Africa. Bull. Cent. Rech. Explor. Prod. Elf-Aquitaine 1, 451-473.

Doyle, J. A., Jardiné, S., and Doerenkamp, A. (1982). Afropollis, a new genus of early angiosperm pollen, with notes on the Cretaceous palynostratigraphy and paleoenvironments of Northern Gondwana. Bull. Cent. Rech. Explor. Prod. Elf-Aquitaine 6, 39-117.

El Albani, A., Fürsich, F. T., Colin, J.-P., Meunier, A., Hochuli, P. A., Martín-Closas, C., et al. (2004). Palaeoenvironmental reconstruction of the basal Cretaceous vertebrate bearing beds in the Northern part of the Aquitaine Basin (SW France): sedimentological and geochemical evidence. Fazies 50, 195-215. doi: 10.1007/ s10347-004-0017-6

Eklund, H., Doyle, J. A., Herendeen, P. S. (2004). Morphological phylogenetic analysis of living and fossil Chloranthaceae. Int. J.
Plant Sci. 165, 107-151. doi: $10.1086 / 380987$

Endress, P. K. (1987). The Chloranthaceae: reproductive structures and phylogenetic position. Bot. Jahrb. Syst. Pflanzengeschichte Pflanzengeographie 109, 153-226.

Endress, P. K., and Honegger, R. (1980). The pollen of Austrobaileyaceae and its phylogenetic significance. Grana 19, 177-182. doi: 10.1080/00173138009425001

Feild, T. S., Arens, N. C., Doyle, J. A., Dawson, T. E., and Donoghue, M. J. (2004). Dark and disturbed: a new image of early angiosperm ecology. Paleobiology 30, 82-107. doi: 10.1666/0094-8373030<0082: DADANI $>2.0 . \mathrm{CO} ; 2$

Feild, T. S., Chatelet, D. S., and Brodribb, T. J. (2009). Ancestral xerophobia: a hypothesis on the whole plant ecophysiology of early angiosperms. Geobiology 7, 237-264. doi: 10.1111/j.1472-4669. 2009.00189.x

Feist-Burkhardt, S., and Pross, J. (1999). Morphological analysis and description of Middle Jurassic dinoflagellate cyst marker species using confocal laser scanning microscopy, digital optical microscopy, and conventional light microscopy. Bull. Cent. Rech. Explor. Prod. Elf-Aquitaine, 22, 103-145.

Friis, E. M., Crane, P. R., and Pedersen, K. R. (2011). Early Flowers and Angiosperm Evolution. Cambridge: Cambridge University Press. doi: 10.1017/CBO9780511980206

Frohlich, M. W., and Chase, M. W. (2007). After a dozen years of progress the origin of angiosperms is still a great mystery. Nature 450, 1184-1189. doi: 10.1038 /nature 06393

Gübeli, A., Hochuli, P. A., and Wildi, W. (1984). Lower Cretaceous turbiditic sediments from the Central Rif chain (northern Morocco). Palynology, stratigraphy and palaeogeographic setting. Geol. Rundschau 73, 1081-1114. doi: 10.1007/BF01820889

He, H. Y., Wang, X. L., Zhou, Z. H., Wang, F., Boven, A., Shi, G. H., et al. (2004). Timing of the Jiufotang Formation (Jehol Group) in Liaoning, northeastern China and its implications. Geophys. Res. Lett. 31, L12605, doi: 10.1029/ 2004GL019790

He, H. Y., Wang, X. L., Zhou, Z. H., Jin, F., Wang, F., Yang, L. K., et al. (2006). 40Ar/39Ar dating of Lujiatun Bed (Jehol Group) in Liaoning, northeastern China. 
Geophys. Res. Lett. 33 L04303, doi: 10.1029/2005GL025274

Heimhofer, U., Hochuli, P. A., Burla, S., Dinis, J., and Weissert, $\mathrm{H}$. (2005). Timing of Early Cretaceous angiosperm diversification and possible links to major palaeoenvironmental change. Geology 33, 141-144. doi: 10.1130/G21053.1

Heimhofer, U., Hochuli, P. A., Burla, S., and Weissert, H. (2007). New records of Early Cretaceous angiosperm pollen from Portuguese coastal deposits: implications for the timing of the early angiosperm radiation. Rev. Palaeobot. Palynol. 144, 39-76. doi: 10.1016/j.revpalbo. 2005.09 .006

Hickey, L. J., and Doyle, J. A. (1977). Early Cretaceous fossil evidence for angiosperm evolution. Bot. Rev. 43, 1-104. doi: 10.1007/BF02860849

Hochuli, P. A., Colin, J. P., and Vigran, J. O. (1989). "Triassic biostratigraphy of the Barents Sea Area," in Correlation in Hydrocarbon Exploration, ed J. Collinson (Graham and Trotman), 131-153. doi: 10.1007/978-94-0091149-9_12

Hochuli, P. A., and Feist-Burkhardt, S. (2004). A boreal early cradle of Angiosperms. Angiosperm-like pollen from the Middle Triassic of the Barents Sea (Norway). J. Micropalaeontol. 23, 97-104. doi: 10.1144/jm.23.2.97

Hochuli, P. A., and Vigran, J. O. (2010). Climate variations in the Boreal Triassic - inferred from palynological records from the Barents Sea. Palaeogeogr. Palaeoclimatol. Palaeoecol. 290, 20-42. doi: 10. 1016/j.palaeo.2009.08.013

Hochuli, P. A., Rebetez, D., SchneebeliHermann, E., and Ramseyer, K. (2012). "Middle Triassic of the Weiach borehole - results from palynology and isotope chemostratigraphy," in 10th Swiss Geoscience Meeting, Abstract, Vol. 7, (Bern), 168.

Hughes, N. F. (1994). The Enigma of Angiosperm Origins. Cambridge, UK: Cambridge University Press.

Krassilov, V., and Schrank, E. (2011). New Albian macro- and palynoflora from the Negev (Israel) with description of a new gymnosperm morphotaxon. Cretac. Res. 32, 13-29. doi: 10.1016/j.cretres.2010. 10.001

Kürschner, W. M., and Herngreen, W. (2010). "Triassic palynology of central and northwestern Europe: a review of palynofloral diversity patterns and biostratigraphic subdivisions," in The Triassic Timescale, Vol. 334, ed S. G. Lucas (London:
Geological Society London Special Publications), 263-283. doi: 10.1144/SP334.11

Kujau, A., Heimhofer, U., Hochuli, P. A., Pauly, S., Morales, C., Adatte, T., et al. (2013). Reconstructing Valanginian (Early Cretaceous) mid-latitude vegetation and climate dynamics based on spore-pollen assemblages. Rev. Palaeobot. Palynol. 197, 50-69. doi: 10.1016/j.revpalbo. 2013.05.003

Litwin, R. J., and Ash, S. R. (1993). Revision of the biostratigraphy of the Chatham Group (Upper Triassic), Deep River basin, North Carolina, USA. Rev. Palaeobot. Palynol. 77, 75-95. doi: 10.1016/ 0034-666790057-2

Magallón, S. (2010). Using fossils to break long branches in molecular dating: a comparison of relaxed clocks applied to the origin of angiosperms. Syst. Biol. 59, 384-399. doi: 10.1093/sysbio/ syq027

Magallón, S., Hilu, K. W., Quandt, D. (2013). Land plant evolutionary timelines: Gene effects are secondary to fossil constraints in relaxed clock estimation of age and substitution rates. Am. J. Bot. 100, 556-573. doi: 10.3732/ajb. 1200416

Maheshwari, H. K. (2007). Deciphering angiosperm origins. Curr. Sci. 92, 606-611.

Markevitch, V. S. (1994). Palynological zonation of the continental Cretaceous and lower Tertiary of eastern Russia. Cretac. Res. 15, 165-177. doi: 10.1006/cres. 1994.1008

Matter, A., Peters, T., Bläsi, H.-R., Meyer, J., Ischi, H., and Meyer, Ch. (1988). Sondierbohrung Weiach-Geologie (Textband). Nagra Technischer Bericht NTB 86-01, (Baden), 470.

Muller, J. (1981). Fossil pollen records of extant angiosperms. Bot. Rev. 47, 1-142. doi: 10.1007/BF02860537

Norris, G. (1969). Miospores from the Purbeck Beds and marine Upper Jurassic of southern England. Palaeontology 12, 574-620.

Pedersen, K. R., Crane, P. R., Drinnan, A. N., Friis, E. M. (1991). Fruits from the mid-Cretaceous of North America with pollen grains of the Clavatipollenites type. Grana 30, 577-590. doi: 10.1080/00173139109 427816

Penny, J. H. J. (1989). New Early Cretaceous forms of the angiosperm pollen genus Afropollis from England and Egypt. Rev. Palaeobot. Palynol. 58, 289-299. doi: 10.1016/0034-666790089-4
Peters, T., Matter, A., Bläsi, H.-R., Isenschmid, Ch., Klebloth, P., Meyer, Ch., and Meyer, J. (1989). Sondierbohrung Leuggern - Geologie (Textband). Nagra Technischer Bericht NTB 86-05, (Baden), 250.

Pocock, S. A. J. (1962). Microfloral analysis and age determination of strata at the Jurassic-Cretaceous boundary in the western Canada plains. Palaeontographica Abt. B 111, 1-95.

Pocock, S. A. J. (1970). Palynology of the Jurassic sediments of western Canada. Part 1. Terrestrial species. Palaeontographica Abt. B 130, 12-72.

Pocock, S. A. J., and Vasanthy, G. (1988). Cornetipollis reticulata, a new pollen with angiospermid features from the upper Triassic (Carnian) sediments of Arizona (U.S.A.), with notes on Equisetosporites. Rev. Palaeobot. Palynol. 55, 337-356. doi: 10.1016/0034-666790092-9

Regali, M. S. P., and Viana, C. F. (1989). Late Jurassic-Early Cretaceous in Brazilian Sedimentary Basins: Correlation with an International Standard Stratigraphic Scale. Rio de Janeiro: Petrobrás Petroleo Brasileiro, S. A.

Schindelin, J., Arganda-Carreras, I., Frise, E., Kaynig, V., Longair, M., Pietzsch, T., et al. (2012). Fiji: an open-source platform for biological-image analysis, Nat. Methods 9, 676-682. doi:10.1038/ nmeth.2019

Schrank, E., and Ibrahim, M. I. A. (1995). Cretaceous (Aptian-Maastrichtian) palynology of foraminifera-dated wells (KRM-1, AG-18) in Northwestern Egypt. Berl. Geowissenschaftl. Abh. Reihe A Geol. Paläontol. 177, 1-44.

Schrank, E., and Mahmoud, M. S. (2002). Barremian angiosperm pollen and associated palynomorphs from the Dakhla Oasis Area, Egypt. Palaeontology 45, 33-56. doi: 10.1111/1475-4983. 00226

Schulz, E. (1967). Sporenpaläontologische Untersuchungen in rhätoliassischer Schichten im Zentralteil des Germanischen Beckens. Paläontol. Abh. Abt. B 2, 541-633.

Smith, S. A., Beaulieu, J. M., and Donoghue, M. J. (2010). An uncorrelated relaxed-clock analysis suggests an earlier origin for flowering plants. Proc. Natl. Acad. Sci. U.S.A. 107, 5897-5902. doi: 10.1073/pnas.1001225107

Soltis, D. E., Moore, M. J., Burleigh, J. G., Bell, C. D., and Soltis, P. S. (2010). Assembling the angiosperm tree of life: progress and future prospects. Ann. Mo. Bot. Gard. 97, 514-526. doi: 10.3417/2009136

Soltis, D. E., Smith, S. A., Cellinese, N., Wurdack, K. J., Tank, D. C., Brockington, S. F., et al. (2011). Angiosperm phylogeny: 17 genes, 640 taxa. Am. J. Bot. 98, 704-730. doi: 10.3732/ajb.1000404

Sun, G., Dilcher, D. L., Zheng, S., and Zhou, Z. (1998). In search of the first flower: a Jurassic angiosperm, Archaefructus, from northeast China. Science 282, 1692-1695. doi: 10.1126/science.282.5394.1692

Staplin, F. L. (1982). "Determination of thermal alteration index from color of exinite (pollen, spores)," in How to Assess Maturation and Palaeotemperatures, Vol. 7, ed. F. L. Staplin (Society of Economic Paleontology and Mineralogy), 7-11.

Stuessy, T. F. (2004). A transitionalcombinational theory for the origin of angiosperms. Taxon 53, 3-16. doi: $10.2307 / 4135484$

Taylor, T. N., Taylor, E. L., and Krings, M. (2009). Paleobotany. The Biology and Evolution of Fossil Plants. Burlington; London; San Diego; New York: Elsevier/Academic Press Inc.

Traverse, A. (2007). Paleopalynology. Dordrecht: Springer.

Trevisan, L. (1988). "Angiospermous pollen (monosulcatetrichotomosulcate phase) from very early Lower Cretaceous of Southern Tuscany (Italy): some aspects," in Proc. 7th Int. Palynol. Congr. Brisb. Aust. Abstr. 165. (Amsterdam: Elsevier).

Trincão, P. R. P. (1990). "Esporos $e$ pólenes do Cretácio Inferior (Berriasiano-Aptiano) de Portugal: Paleontologia e Biostratigrafia. $\mathrm{PhD}$ Thesis. Lisbon: Universidade Nova de Lisboa, 1-312.

van Konijnenburg-van Cittert, J. H. A. (2010). The Early Jurassic male ginkgoalean inflorescence Stachyopitys preslii Schenk and its in situ pollen. Scripta Geol. 7, 141-149.

Vigran, J. O., Mangerud, G., Mork, A., Bugge, T., and Weitschat, W. (1998). Biostratigraphy and sequence stratigraphy of the Lower and Middle Triassic deposits from the Svalis Dome, central Barents Sea, Norway. Palynology 22, 89-141. doi: 10.1080/01916122. 1998.9989505

Vigran, J. O., and Thusu, B. (1975). Illustrations and Distribution of the Jurassic Palynomorphs of Norway: Illustrations of Norwegian Microfossils. Trondheim: NTNFkontinentalsokkelkontor. 
Walker, J. W., and Walker, A. G. (1984). Ultrastructure of Lower Cretaceous angiosperm pollen and the origin and early evolution of flowering plants. Ann. Mo. Bot. Gard. 71, 464-521. doi: 10.2307/2399035

Wang, X. (2000) "Pollen record of early angiosperms in NE China," in Palynofloras and Palynomorphs of China ed Z. Song (Hefei: Press University Science and Technology China), 96-100.

Wang, X. (2009). "New fossils and new hope for the origin of angiosperms," in Evolutionary Biology: Concepts, Modelling, and Application, ed P. Pontarotti (Berlin; Heidelberg: Springer-Verlag), 51-70. doi: 10.1007/978-3-642-00952-5_3

Wang, X. (2010). Schmeissneria: an angiosperm from the Early Jurassic. J. Syst. Evol. 48, 326-335. doi: 10.1111/j.1759-6831.2010.00090.x
Wang, X., Duan, S. Y., Geng, B. Y., Cui, J. Z., and Yang, Y. (2007). Schmeissneria: a missing link to angiosperms. BMC Evol. Biol. 7:14. doi: 10.1186/1471_2148-7-14

Zavada, M. S. (1984a). Angiosperm origins and evolution based on dispersed fossil pollen ultrastructure. Ann. Mo. Bot. Gard. 71, 440-459. doi: 10.2307/2399034

Zavada, M. S. (1984b). The relation between pollen exine sculpturing and self-incompatibility mechanisms. Plant Syst. Evol. 147, 63-78. doi: 10.1007/BF00984580

Zavada, M. S. (2007). The identification of fossil angiosperm pollen and its bearing on the time and place of the origin of angiosperms. Plant Syst. Evol. 263, 1-2, 117-134. doi: 10.1007/s00606-006-0495-9

Zheng, S. L., and Wang, X. (2010). An undercover angiosperm from the Jurassic of China. Acta Geol. 84, 895-902. doi: 10.1111/j.17556724.2010.00252.x

Zhou, S., Zhou, L., Wang, W., Wu, Y., and Yang, X. (2009). Cretaceous Palynostratigraphy, with Emphasis on Angiosperm Pollen Grains and their Evolution in Jiangsu Province, China. Nanjing: Sinopec, Huadon Company. (in Chinese with English abstract).

Conflict of Interest Statement: The authors declare that the research was conducted in the absence of any commercial or financial relationships that could be construed as a potential conflict of interest.

Received: 31 May 2013; accepted: 15 August 2013; published online: 01 October 2013.
Citation: Hochuli $P A$ and FeistBurkhardt S (2013) Angiosperm-like pollen and Afropollis from the Middle Triassic (Anisian) of the Germanic Basin (Northern Switzerland). Front. Plant Sci. 4:344. doi: 10.3389/fpls.2013.00344 This article was submitted to Plant Evolution and Development, a section of the journal Frontiers in Plant Science. Copyright (c) 2013 Hochuli and FeistBurkhardt. This is an open-access article distributed under the terms of the Creative Commons Attribution License (CC BY). The use, distribution or reproduction in other forums is permitted, provided the original author(s) or licensor are credited and that the original publication in this journal is cited, in accordance with accepted academic practice. No use distribution or reproduction is permitted which does not comply with these terms. 